\title{
Developing auto-Didactic (Self-Learning) Skills by Using Social Networking
}

\author{
Dr. Mohamed Abdullah Turky ${ }^{1}$, Nardeen Yousry Soliman ${ }^{2}$ \\ ${ }^{1}$ Digital Design and Publishing Research Unit (DDPRU), Faculty of Education, Tanta University, Egypt \\ ${ }^{2}$ Demonstrators, Department of Mental Health, Faculty of Education - Tanta University
}

\begin{abstract}
The recent research aims at checking the effectiveness of participating in the social networking sites on auto-didactic skills for university students. The study sample was formed of (30) students enrolled in higher studies of instructional education. The research tools were of a list of tasks students do to learn new skills in a group by using Google applications namely Facebook through having beers exchange subjects and media. The researcher designed a note card to evaluate students' participation inside the group in addition to designing ( 30) clause - test to measure skills of auto didactic. The results showed differences with statistical significance concerning skills of auto-didactic for the study sample in the pre and post application for the benefit of the post application. The above-mentioned card carried also differences with statistical significance. There is a positive approach for the study sample to share files, folders and media related to skills of Google applications.
\end{abstract}

Keywords: Auto-didactic, Self-Learning, social networking, social participation, Google applications.

\section{Introduction}

Auto-didactic is considered one of the most important ways which employs skills of learning effectively; the thing which upgrades humans behaviorally and cognitively and enables them to keep in touch with their coming age; the style in which we teach pupils how to learn what they want by themselves and how to acquire autodidactic skills which are suitable for all ages and all time inside and outside schools which is called lifelong learning. Hence, learning is regarded as one of the most outstanding outputs at schools. In fact, it is so difficult for any theory to put a definite and an accurate definition for learning .Jonassen and his colleagues argue that learning is a bio chemical interaction inside the brain. Behaviorists see that learning is relatively ongoing change in behavior. Whereas, cognizant see learning as processing information and memorizing; the thing which is confirmed by the classical school. (Jonassen\&Howland, 2003) think that learning is social negotiation, skills of thinking, activity, sensitive agreement related to environment and building knowledge .In 1980s, theories and auto-didactic models started to show what the learner should do to achieve success in learning (Boekaerts \& Zeinder, 2000). Auto-didactic has many definitions such as self- Detracted learning and self - regulated learning. Besides, it is defined as a way to encourage persons to be learners on their own which is based on self- learning programs (Zimmerman, 1994). ( Ghbayen, 2001) confirms that self-learner programs increases learner's 
self-confidence, his / her ability to create in addition to motivating him / her to achieve progress and increasing their awareness of affective and cognitive problems during learning process. Roles of school and society should be supplementary to lead to better results. Society itself needs that type of learning which empowers students' role and provides them with motivation to work and learn together. Autodidactic is based on psychological bases which are related to psychology and educational ones which are related to education science. These bases can be summarized in some terms such as motivating and tempting maturity, reinforcement, individual differences, interacted responses and being clever in learning. Studies of (Hussamou\&Al-Abdullah ,2011) confirmed the effect of auto-didactic on functioning skills of synchronal and non-synchronal electronic dialogue for students in Teshreen University. The results referred to existence of significant differences related to the non-synchronal vocal electronic dialogue which is between the arithmetic means for students before and after the application of the accumulative test concerning the cognitive side. These differences were also clear in the practical side card for skills of synchronal and non- synchronal vocal electronic dialogue.

\section{Methodology}

The researcher used the analytic descriptive method before, during and after the study in which he checked the research aims and variables and tried to handle all axes benefiting from the previous studies in this field dealing with the role of social networking sites in developing auto - didactics and trying to test the following assumptions which refers that there is no statistical significance at significant level $(0,05)$ which measure grades of sample members and the role of social networks to develop skills of auto didactics. The researcher designed (15)clause- questionnaire divided into psychological affective field including 9 clauses and school attainment field including 6 clauses. (Lekret) quintuple measure was used to measure responses of the study sample for questionnaire clauses according to table (1):

Table (1): grades of lekret quintuple measure

\begin{tabular}{|c|c|c|c|c|c|}
\hline Response & $\begin{array}{c}\text { Extremely } \\
\text { agreeable }\end{array}$ & Agreeable & Neutral & $\begin{array}{c}\text { not } \\
\text { agreeable }\end{array}$ & $\begin{array}{c}\text { Not very } \\
\text { agreeable }\end{array}$ \\
\hline Grade & 5 & 4 & 3 & 2 & 1 \\
\hline
\end{tabular}

The researcher chose grade (1) for response "not very agreeable" so, the relative scale in this case is $(20 \%)$ which is suitable for that response Also, correlation coefficient is measured between clauses of psycho affective field and clauses of school attainment field and the total grade of the questionnaire.

Table (2) correlation coefficient between every clause in psycho effective, school attainment and total degree of the questionnaire.

\begin{tabular}{|l|l|l|}
\hline \multicolumn{1}{|c|}{ Field } & \multicolumn{1}{c|}{$\begin{array}{c}\text { Correlation } \\
\text { coefficient }\end{array}$} & $\begin{array}{c}\text { Significance } \\
\text { level }\end{array}$ \\
\hline Psycho affective & .781 &., 000 \\
\hline School attainment & .561 &., 000 \\
\hline
\end{tabular}

*The statistically significant correlation is at level $\alpha=0,05$. Moreover, the data in the above table confirms that the field is suitable for its purpose The researcher made a list of Google application skills such as( Google sites -Google doc )for the research sample; the skills which students should acquire by themselves through the researcher's general guide. The researcher asked the study sample to make a Facebook group to contact and exchange experience. Then, the data from the questionnaire has been statistically processed by using SPSS program to get the following Result.

\section{Result}

To assign the used criterion in that study, length of cells in (lekret) quintuple measure was defined by calculating the extent between measure grades $(5-1=4)$. After that, the researcher divided that result by the utmost value in the measure to get the cell length $(0.80)$ was added to the least value in the measure (1) to determine the highest limit for that cell as shown in the following Table :- 


\begin{tabular}{|c|c|c|}
\hline $\begin{array}{c}\text { Agreement } \\
\text { degree }\end{array}$ & $\begin{array}{c}\text { Relative } \\
\text { scale }\end{array}$ & $\begin{array}{c}\text { Length of } \\
\text { the cell }\end{array}$ \\
\hline Agreeable with a very little degree & $20 \%$ to $36 \%$ & From 1 to 1,80 \\
\hline Agreeable with little degree & $<36 \%$ to $52 \%$ & $<1,80$ to 2,60 \\
\hline Fairly agreeable & $<52 \%$ to $68 \%$ & $<2,60$ to 3,40 \\
\hline Agreeable with a great degree & $<68 \%$ to $84 \%$ & $<3,40$ to 4,20 \\
\hline $\begin{array}{l}\begin{array}{l}\text { Agreeable with a very great } \\
\text { degree }\end{array} \\
\end{array}$ & $\begin{array}{l}<84 \% \text { to } \\
100 \%\end{array}$ & $<4,20$ to 5 \\
\hline
\end{tabular}

To interpret study results and response level, the researcher depended on arranging arithmetic means for the fields' level in general and for clauses level in every field in particular. The agreement degree was defined according to the criterion used in the study. Also, differences between arithmetic means for clauses of all fields were used as shown in the following table:

Table (4) statistical significance for differences between arithmetic means of performance degrees for the study sample

\begin{tabular}{|c|c|c|c|c|c|}
\hline $\begin{array}{l}\text { Field of } \\
\text { questionnaire }\end{array}$ & $\begin{array}{l}\text { Arithmetic } \\
\text { mean }\end{array}$ & $\begin{array}{l}\text { Standard } \\
\text { deviation }\end{array}$ & $\begin{array}{c}\text { Degrees } \\
\text { of } \\
\text { freedom }\end{array}$ & $\begin{array}{c}T \\
\text { value }\end{array}$ & $\begin{array}{c}\text { Level of } \\
\text { significance }\end{array}$ \\
\hline $\begin{array}{l}\text { Psycho } \\
\text { affective }\end{array}$ & 48,2 & 9,77 & \multirow{3}{*}{30} & \multirow{3}{*}{42,66} & \multirow{3}{*}{0,05} \\
\hline $\begin{array}{l}\text { School } \\
\text { attainment }\end{array}$ & 55,8 & 8,15 & & & \\
\hline $\begin{array}{l}\text { The whole } \\
\text { questionnaire }\end{array}$ & 44,43 & 10,6 & & & \\
\hline
\end{tabular}

The above -mentioned table shows the following:-

- The arithmetic mean for all clauses of the psycho-affective field mentioned in the questionnaire of the auto-didactic skills measure caused by the social participations in developing self-skills was (48.2) whereas the standard deviation was (9.77)so the relative scale was( $79 \%)$.

- The arithmetic mean for all clauses of the school attainment field mentioned in the auto didactic skills measure caused by the social participations in developing self-skills was (55.8). Whereas, the standard deviation was (8.15), so the relative scale was $(83 \%)$.

- The arithmetic mean for all clauses of the auto didactic skills measure questionnaire caused by social participations in developing self-skills was (44.43). Whereas, the standard deviation was (10.6) so the relative scale was $(86 \%)$.

\section{Discussion}

Through analyzing the previous results for the research sample in the auto didactic skills measure questionnaire in both fields of psycho affective and school attainment, it so clear that social participation for the study sample affects greatly the response to the questionnaire due to the following reasons:

- Social participation for the study sample by using social networking sites leads to exchanging experience between students regarding what they learn.

- Neglecting time and place factors which enable the study sample to communicate during their practice on Google applications.

- Developing skills of students and their experience because those persons do evaluation for their peers spontaneously concerning their practical skills and needs.

- Auto didactic skills for the study sample were developed and improved in the school attainment field especially the skillful experience.

- There is a good balance in the psychoaffective field in addition to comfort between members of the study sample during exchanging information and experience for the applications.

\section{Recommendations}

- It is necessary to generalize the use of auto didactic skills during students practice at university on technological skills.

- social networking sites is considered an essential tool to increase communication between teachers and students in a hand and between students and each other in another hand. 
- Taking care of psycho-affective aspect while teaching students at universities which leads to achieving the hopeful didactic aims.

- It is necessary for the auto didactic skills to be included while designing the educational activities in the university curriculum. columns.

\section{Conclusion}

Auto-didactic skills are necessary to develop personal and self-aspects for university students which support the psycho-affective aspects and lead to achieve the didactic aims. It is important to make good use of social networking sites in the educational process.

\section{Acknowledgements}

Finally, I thank my colleagues in the Research and Design and Digital Publishing Unit for their moral support to me in carrying out this study, and also thank the graduate students who specialize in educational technology for their perseverance during the application of the study.

\section{References}

[1] Ghbayen, Omar (2001) Self-learning in educational bags, first edition, Oman: Al Masirah House for Publishing, Distribution and Printing.

[2] Hussamou, Al-Abdullah (2011). The effect of self-learning on employing simultaneous and asynchronous electronic conversation skills among students of the class teacher at Tishreen University. Syria

[3] Jonassen, D., Howland, J., Moore, J. \& Marra, Rose (2003) Learning to solve problem with technology a constructive prospective. (2nd ed.). Merrill Prentice Hall, NJ.

[4] Boekaerts, M. (1999). Self-regulated learning: where we are today. International Journal of Educational Research, 31 (6), $445-457$
[5] Zimmerman, B. (1994). Dimensions of Academic Self-Regulation: A Conceptual Framework for Education. In D. Schunk \& B. Zimmerman (Eds). Self-Regulation of Learning and Performance: Issues and Educational Applications. (P. 1-19). NJ. Lawrence Erlbaum Associates 